\title{
61. 空間共有者と照明方式が快適照明条件に与える影響に関する主観評価実験
}

\author{
望月悦子 \\ 岩田利枝 \\ (東海大学大学院) \\ (東海大学) \\ 板西俊郎 \\ 長谷部徹 \\ ((株) ニトリ $)$ \\ (東海大学大学院)
}

1.はじめに 光源の色温度と照度の 組み合わせにより快適照明条件は異 なるとされている1)。住宅居室に求め られる雰囲気性は作業行為によって 異なることも示されており2)、その他 に照明方式や室空間を共有する人に よっても居室に求められる雰囲気は 異なると考えられる。本研究では住 宅居室を取り上げ、照度, 色温度, 照 明方式の組み合わせ条件がつくる照

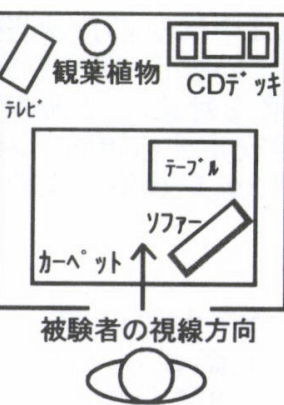

図 1. 評価模型装置

明空間の雰囲気性を定量的に把握し、室空間を共有する人によって快 適照明条件がどのように異なるか明らかにすることを目的としている。 2. 実験概要 評価には図 1 に示す縮尺 $1 / 10$ の評価模型装置を用いた。 模型内の照明方式は可変であり、図 1 に示寸 4 種類とした。赤, 緑, 青, 昼白色の 4 種類の蛍光灯各 12 本からなる光源装置を用いて、表 1 に示寸条件に模型内の照明環境を設定した。各照明方式について色温 度 4 条件と照度 3 条件を組み合わせ、全 48 条件について実験を行った。 被験者は健康な男女計 21 名 (平均年齢 22.3 歳) とし、被験者は十分に 暗順応した後、呈示された評価模型装置内の光環境の印象を 15 個の形 容詞対で7段階評価した。さらに模型内の空間を共有する人によって、 呈示された照明条件が適するか否か申告を行った。

3. 結果・考察 3.1 照明空間の雾囲気性評価 15 個の形容詞対の申告 平均值を対象に、相関係数行列を用いて主成分分析を行った。表 2 に 結果を示す。第3 主成分までで照明空間の雾囲気性を $90 \%$ 以上説明で きることがわかった。第1主成分は「はっきりした」「やわらかい」な ど「明瞭性」に関する主成分、第 2 主成分は「つまらない」「にぎやか な」など「楽しさ」に関する主成分、第 3 主成分は「人工的な」「派手 な」など「自然さ」に関する主成分であった。各主成分が照度，色温

\begin{tabular}{c|c|c|c|c|c}
\multicolumn{5}{c}{ 表 1. 実験条件 } \\
\hline \multirow{2}{*}{ 色温度 $[\mathrm{K}]$} & \multicolumn{5}{|c}{ 照度 $[\mathrm{x}]$} \\
\hline 2800 & & $\mathrm{O}$ & $\mathrm{O}$ & & $\mathrm{O}$ \\
\hline 3800 & & $\mathrm{O}$ & $\mathrm{O}$ & $\mathrm{O}$ & \\
\hline 5000 & $\mathrm{O}$ & $\mathrm{O}$ & $\mathrm{O}$ & & \\
\hline 6500 & $\mathrm{O}$ & $\mathrm{O}$ & $\mathrm{O}$ & & \\
\hline
\end{tabular}

表 2. 主成分分析結果

\begin{tabular}{|c|c|c|c|}
\hline & 主成分 1 & 主成分 2 & 主成分 3 \\
\hline & 明瞭性 & 楽しさ & 自然さ \\
\hline 固有值 & 6.843 & 4.643 & 2.121 \\
\hline 需与钴 & 0.456 & 0.310 & 0.141 \\
\hline 累積寄与率 & 0.456 & 0.766 & 0.907 \\
\hline はっきりした & -0.371 & -0.018 & 0.074 \\
\hline うっとうしい & 0.333 & 0.061 & 0.281 \\
\hline まふししくない & 0.333 & -0.149 & -0.179 \\
\hline 重い & 0.330 & -0.031 & 0.081 \\
\hline 宕㵖な & 0.319 & 0.049 & 0.321 \\
\hline 暗い & 0.314 & -0.236 & 0.019 \\
\hline やわらかい & 0.313 & 0.229 & -0.138 \\
\hline つまらない & 0.056 & -0.416 & 0.227 \\
\hline にきややかな & -0.045 & 0.432 & 0.023 \\
\hline うるさい & 0.005 & 0.358 & 0.392 \\
\hline 人工的な & -0.190 & -0.174 & 0.515 \\
\hline 派手な & -0.173 & 0.283 & 0.405 \\
\hline 冷大心 & -0.241 & -0.329 & 0.151 \\
\hline 聞鎖的な & 0.229 & -0.283 & 0.290 \\
\hline 非演出的 & -0.226 & -0.274 & -0.115 \\
\hline
\end{tabular}

表3.主成分と照明要素分散分析

**: $1 \%$ 有意 *:5\% 有意

\begin{tabular}{c||c|c|c}
\hline \multicolumn{5}{c|}{ 要因 } & 主成分 1 & 主成分 2 & 主成分 3 \\
\hline 照度 & $* *$ & $* *$ & $* *$ \\
\hline 色温度 & $* *$ & $*$ & \\
\hline 照明方式 & & & $* *$ \\
\hline 照度 $\times$ 色温度 & & & \\
\hline 照度 $\times$ 方式 & & & $* *$ \\
\hline 色温度 $\times$ 方式 & & & $*$
\end{tabular}
度, 照明方式の三要素のいずれで決まるか分散分析を 行った結果を表 3 に示す。

3.2 空間共有者と快適照明範囲 図 2 に一例として、全 般照明の場合、空間を共有する人によって快適照明範 囲1)がどのように異なるかを示す。Kruithofが示した快 適照明範囲内でも、空間を一人で使用する場合は色温 度が低い方が、空間を複数の友人と使用する場合は照 度が高い方が照明空間として適することがわかった。 4.まとめ 住宅居室の雰囲気性を決定する照明要素と空 間共有者による快適照明範囲の違いを被験者実験によ り明らかにした。

【引用文献】1) Kruithof, A. A.: Tubular luminescence lamps for general illumination, Philips Tech. Review, 6, pp.65-96, 1941 2)中村 肇 : Kruithof (クルイトフ) のカーブは正しいか?,照明学会誌 ,第 85 巻, 第 9 号,pp.793-795,2001 年

空間を 1 人で使用する場合 複数友人と使用する場合
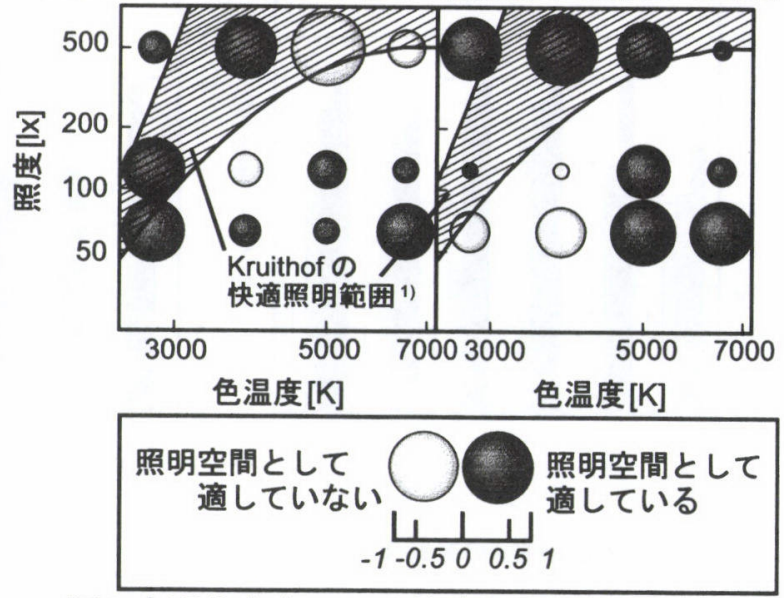

図2.空間共有者による快適照明範囲の逴い

Subjective Experiment on the Effects of Co-occupants and Lighting Fittings on the Comfortable Lighting Conditions

Etsuko MOCHIZUKI, Toshie IWATA, Toshirou BANZAI and Toru HASEBE 